\title{
Liberalisation in a World of Second Best: \\ Evidence on European Network Industries
}

\author{
Mehmet Ugur
}

\begin{abstract}
$\underline{\text { Abstract }}$
This article reports mixed results about the impacts of liberalisation in European network industries. Telecommunications prices have fallen and converged across EU-15, but electricity and gas prices have either increased or diverged. Productivity has increased, but mainly as a result of falling employment in absolute and relative terms. Liberalised industries are still characterised by high levels of market concentration and low levels of transparency and market integration. These findings are in line with the predictions of the theory of second best and suggest that the case for liberalisation of network industries has been oversold.
\end{abstract}

KEY WORDS: Liberalisation, network industries, second-best, public policy, European Union.

Mehmet Ugur is Jean Monnet Reader in European Political Economy at the University of Greenwich Business School. He studied at the Middle East Technical University (Ankara) and London School of Economics. His research focuses on and economic governance, regional integration theory, integration-globalisation linkages, and EU-Turkey relations. His publications include Turkey and European Integration (Routledge, 2004, edited wit N. Canefe), Open Economy Macroeconomics (Routledge, 2003), The European Union and Turkey: An Anchor/Credibility Dilemma (Ashgate, 1999).

\section{Address:}

University of Greenwich, Business School, Old Royal Naval College, Park Row, London SE10 9LS. Tel: 0208331 8913; E-Mail. M.Ugur@gre.ac.uk 


\section{Liberalisation in a World of Second Best: Evidence on European Network Industries*}

\section{Introduction}

Network industries in this article refer to services of general economic interest such as gas, electricity, rail transport and telecommunications. In Europe, these industries had been kept under public ownership because of their natural monopoly characteristics. ${ }^{1}$ In 15 members of the European Union (EU-15), network industries account for about 10\% of total production and $7 \%$ of total employment. In terms of weight in the overall inflation, they contribute by about 7\% to the harmonised index of consumer prices (HICP) (Martin et al, 2005: 8). Their overall economic significance is greater than what the figures above would suggest because they constitute a significant part of the European infrastructure and their output is utilised as inputs in a wide range of industries. Because of this particular status, liberalisation is bound to affect not only the particular industries involved, but also the overall economic performance of EU-15.

The aim of this article is to provide verifiable answers to a number of questions concerning the extent of liberalisation in network industries and the implications of liberalisation for prices, employment, productivity, and consumer satisfaction. The data we use is compiled from a number of sources, including the Eurostat, the Groningen Growth and Development Centre, the Copenhagen Economics, Internal Market Directorate-General of the European Commission, and a number of European Regulatory Groups. The extent of liberalisation and its implications will be discussed in the context of the theory of second-best.

Section 2 of the article describes the general characteristics of the network industries and elaborates on why the theory of second best is appropriate for the study of liberalisation in these industries. Section 3 reports aggregate evidence on the extent of network industry liberalisation and its observable impacts on prices, productivity, employment, and consumer satisfaction. Section 4 provides evidence on persistent market imperfections and on the absence of cross-country correlations between liberalisation and expected gains in terms of

\footnotetext{
* I would like to thank Zeinab Suliman for her help in the collection of the data used in this article. I would also like to thank Copenhagen Economics for allowing access to their database on market opening.
} 
prices and customer satisfaction. The evidence provided in sections 3 and 4 relates to four industries for which data could be obtained: telecommunications, gas, electricity, and rail transport. Finally, the conclusions summarise the main findings and point out the parallelism between the latter and the predictions of the second-best theory. The findings suggest that the legitimacy of network industry liberalisation is highly likely to remain a contested issue. This is in contrast to the single market programme of 1986-92, which had constituted a less cumbersome move towards a first-best environment for trade through removal of non-tariff barriers and harmonisation of trade-related standards.

\section{Characteristics of network industries and relevance of the theory of second best}

Historically, European network industries have been organised as natural monopolies under public ownership. There have been three main reasons for this type of industrial organisation: (i) natural monopoly due to decreasing average costs over the range of relevant output; (ii) non-divisibility of the network and high cost of duplicating the network infrastructure; and (iii) public service obligations. This is in contrast to the type of industrial organisation that had been adopted in the United States since the early years of the $20^{\text {th }}$ century. In the US model, private ownership combined with regulation has been the norm. Therefore, liberalisation and the emergence of national/European regulators can be interpreted as moves towards the US model even though privatisation is not a necessary condition in the emerging European model.

The rationale for the natural monopoly status and public ownership of the European network industries has begun to be questioned since mid-1980s. One reason is that technological developments have reduced the significance of network non-divisibility by allowing for different modes of access and different methods of measurement and charging. Secondly, the fiscal constraint has induced European governments to reduce the subsidies granted to these industries and/or increase their revenues from privatisation. Thirdly, the Single Market Project has reduced non-tariff barriers significantly and made intra-EU trade increasingly sensitive to distortions emanating from non-trade policies. Because network industry products and services were used as inputs for the production of traded goods, different levels of subsidisation began to be seen as violations of the level playing field in the single European market. Finally, and as a natural extension of the Single Market experience, liberalisation began to be considered as a necessary measure that would increase competition and encourage 
technological innovation. Technological innovation in network industries was a crucial issue not only because of the strategic importance of these industries but also because of the indispensable role that innovation plays in increasing total factor productivity.

Considered from a political economy perspective, these factors go a long way in explaining not only the timing of the European liberalisation effort but also the ease with which an alliance could be struck between European governments and the EU Commission. On the one hand, fiscal and strategic considerations have led to the convergence of national government preferences towards liberalisation and deregulation. ${ }^{2}$ On the other hand, the achievement of convergent goals required the existence of a rule-setter/enforcer who would ensure the sustainability of the liberalisation game. This constellation provided a favourable environment that enabled the Commission to develop and secure political support for its strategy of network industry liberalisation.

The liberalisation of European network industries has been guided by three simple principles: (i) unbundling of upstream and downstream operators; (ii) non-discriminatory third-party access to the network; and (iii) supply of transparent information on access charges and different types of tariffs. Unbundling is considered as necessary to prevent cross-subsidisation and to reduce the ability of the incumbents to control upstream and downstream markets. Non-discriminatory third-party access is necessary to inject a degree of market contestability through new entry. Finally, transparency of prices and access charges is necessary to prevent discrimination against new entrants and/or in favour of the incumbents' affiliates.

In terms of implementation, liberalisation has been designed as a gradual process. Initially, the process began with the liberalisation of the least-controversial sector in terms of technology and political economy. That is why liberalisation first began in 1990 in the telecommunications sector, where expansion of the product range and rapid technological change have been instrumental in challenging the natural monopoly aspects of the industry and the case for public ownership. Then, market opening was extended to other services such as gas and electricity in the second half of the 1990s. Finally, it was introduced into rail transport at the beginning of 2000s. The other dimension of gradualism was observed in terms of sequencing. The liberalisation effort began with unbundling, progressing through thirdparty access and culminating in the imposition of transparency rules and establishment of EUlevel regulatory institutions. (See, Napolitano, 2005; Geradin, 2006). 
The EU presents liberalisation as a set of measures aimed at increasing efficiency and consumer welfare through increased competition and technological innovation (EU Commission, 2005; 2007). A comprehensive study undertaken by Copenhagen Economics (2005) for the Internal Market Directorate-General of the EU Commission provides evidence on the positive effects of liberalisation on welfare and employment. Copenhagen Economics estimate that liberalisation has led to an increase of $1.9 \%$ in welfare and $0.3 \%$ in overall employment from 1990-2001. These gains are relative to the base-year values in 2001 and are equivalent to Euros 98 billion per year over the 1990-2001 period. Another study by Martin et al (2005) reports that panel data estimations point out a significant decline in prices due to regulatory reforms in European network industries.

This article argues that such estimations are too optimistic because they ignore the complications that are likely to arise when a policy action constitutes a move within a secondbest environment as opposed to a move from a second-best to a first-bets environment. Market opening reforms in European network industries do not constitute a move from the second- to the first-best not only because of the continuity of the distortions in the rest of the economy; but also, and more importantly, because of the persistence of the distortions within the liberalised industries themselves.

One characteristic of the network industries that causes persistent distortions is large market shares controlled by incumbents. The evidence we present in section 4 below indicates that 3 major companies has retained control of more than $75 \%$ of the market in all of the industries examined in this article - namely, gas, electricity, rail transport and telecommunications. Another characteristic of the network industries is low demand and supply elasticities. While low demand elasticities enable network industry firms to increase their price-cost margins (mark-ups) without a significant fall in demand, low supply elasticities are conducive to price hikes in the face of capacity constraints. The combination of large market shares and low demand elasticities is conducive to increased mark-ups - as can be seen from the Lerner index. $^{3}$ The welfare gains predicted in the literature do not take account of the probability that the levels of mark-up may persist even if prices fall after market opening.

The third characteristic of network industries is the persistence of the economies of scale (falling average costs) and high levels of sunk costs even after liberalisation. This 
combination acts as a deterrent to new entry or has adverse effects on efficiency even if new entry is encouraged by regulation. Finally, regulation of liberalised industries may prove ineffective in securing competition due to the persistence of economies of scope, which arises from joint supply of differentiated products using the existing network infrastructure. Economies of scope involve cost advantages due to joint production and reduce the effectiveness of the regulators for two reasons. First, it enables the incumbents to deter new entry into profitable market segments through price cuts. Secondly, economies of scope and joint production enable the incumbents to impose excessive prices in non-profitable segments by using joint production costs as a means of concealing the true cost in the non-profitable segments. (For further discussion, see ERG, 2005a; Buehler, 2005).

Because of these likely complications, it is appropriate to examine the liberalisation of network industries as a policy move within the second-best environment, which is characterised by the existence of distortions that prevent the achievement of Pareto-optimum equilibrium. A key finding in the theory of second-best is that a partial removal of distortions is not necessarily conducive either to first-best Pareto-optimality or welfare improvement. As Lipsey and Lancaster (1956: 12) have indicated;

... in a situation in which there exist many constraints which prevent the fulfilment of the Paretian optimum conditions, the removal of any one constraint may affect welfare or efficiency either by raising it, by lowering it, or by leaving it unchanged.

The reason why a partial move towards the first best does not necessarily improve welfare or efficiency is that the satisfaction of necessary conditions (e.g., market opening and deregulation of network industries) does not necessarily imply the satisfaction of sufficient conditions (i.e., the removal of all distortions that prevent the achievement of a perfectly competitive general equilibrium). This is why Lipsey and Lancaster (1956: 17) criticise 'piecemeal welfare economics' for basing its policy recommendations on the 'belief that a study of the necessary conditions for a Paretian welfare optimum may lead to the discovery of sufficient conditions for an increase in welfare.' A similar conclusion is derived by Baumol (1965: 138), who states that 'partial policy measures which eliminate only some of the departures from the optimal arrangement may well result in a net decrease in social welfare.' 
Policy recommendations based on computable general equilibrium simulations may be based on too optimistic assumptions that ignore the complications highlighted by the theory of second best. This may be the case for two reasons. First, we may never be able to identify and implement all of the sufficient conditions for Pareto efficiency. Secondly, even if it is possible to identify the sufficient conditions the cost of implementing the policy designed to satisfy them may outweigh its benefits. These problems are stated explicitly in a recent article by Lipsey (2007: 5), in which he draws attention to the following:

\footnotetext{
Market structures are rarely competitive enough to make marginal cost equal to price: oligopoly, monopolistic competition and monopoly vastly outnumber cases where firms are price takers. Some price setting behaviour occurs because of technologically determined factors such as scale economies, some because of firm-determined entry barriers and product characteristics and some because of policy.'
}

To the extent this is the case, it may not be possible to distinguish between the technologyinduced and policy-induced wedge between marginal costs and prices. Trying to eliminate the wedge when it is induced by policy or firm behaviour may be welfare-improving if all other distortions are also removed. However, liberalisation policy aimed at eliminating a technology-induced wedge will be welfare-reducing. Of course, the existence of such problems does not imply that liberalisation reforms are necessarily welfare-reducing. For example, Bhagwati et al (1969: 1009) argue that

A small dose of a policy that has some effect on the distorted margin is better than no policy at all, because the initial marginal gain from mitigating the distorted market is of first order while the initial welfare cost from introducing the new distortion is of second order.

Similarly, Rakowski (1980) states that a movement towards Pareto optimality may not necessarily increase welfare, but if distortions are 'sufficiently minor and insignificant' departures from Pareto optimality are likely to be 'minor and insignificant'. In other words, a partial move towards Pareto-optimality may reduce the welfare loss even if it does not ensure the achievement of Pareto optimality.

These arguments are intuitive and inform economic policy decisions to a large extent. However, as Lipsey (2007) indicates, these arguments would hold water only if the policy introduces a new distortion that was previously zero! In other words, a partial movement 
towards the first best may not even guarantee a reduction in welfare losses if it affects existing distortions. This is very likely to be the case because the main aim of the policy is to remove existing distortions. That is why Blackorby (1990: 757) remains convinced that 'moving prices closer to marginal costs would not lead to an improvement in welfare, actual or potential.'

Unfortunately, welfare implications estimated by simulation studies of market opening in European network industries do not take into account such complications. They assume that the costs of remaining or newly-introduced distortions are zero and estimate only the static and/or dynamic effects that result from changes in prices and/or productivity. That is why such estimations are too optimistic and as such they are either inaccurate or inappropriate bases for policy recommendations or evaluations. This does not imply that the estimates are totally irrelevant and that prices may not fall or productivity may not improve after liberalisation. What is indicated here is that the positive impact of liberalisation reforms on prices and productivity must be discounted by the costs of distortions that may be left untouched or those that may be even exacerbated as a result of the partial nature of the liberalisation reforms.

\section{Impact of liberalisation on prices, productivity, employment and consumer satisfaction in EU-15.}

As indicated above, the earliest EU-level liberalisation reforms were introduced in the telecommunications sector in 1990. This was followed by the gas and electricity liberalisation from 1996 onwards. Rail transport liberalisation through EU-level legislation began in 1991 but it remained highly limited until the adoption of the first railways package in early 2000s. In their work for the EU Commission, Copenhagen Economics have constructed a market opening index based on the implementation of market opening milestones that reflect the implementation of national and EU-level legislation. The index takes values between 0 and 1 , with 0 corresponding to closed/protected markets and 1 corresponding to fully liberalised markets. The results are given in Table 1 below.

As can be seen from Table 1, market opening has remained limited in most of the sectors until mid-1990s. This is due partly to the time-lag between legislation and implementation and 
partly to reluctance of national governments either to implement existing legislation or to agree to sufficient levels of liberalisation. The latter reason is the more significant because EU legislation tends to provide a framework rather than a detailed programme for reform. Following the slow start, the value of the market opening index began to increase from mid1990s onwards. However, even then the level of market opening remained less than $50 \%$ until 2000 in almost all of the sectors. By 2003, the level of market opening ranged between 50$70 \%$.

Table 1: Market opening index (MOI) for network industries: EU-15

\begin{tabular}{|l|c|c|c|c|c|}
\hline & Telecoms & Gas & Electricity & $\begin{array}{l}\text { Rail - } \\
\text { Passengers }\end{array}$ & $\begin{array}{l}\text { Rail - } \\
\text { Freight }\end{array}$ \\
\hline 1990 & 0.08 & 0.00 & 0.12 & 0.01 & 0.07 \\
\hline 1991 & 0.11 & 0.00 & 0.12 & 0.04 & 0.08 \\
\hline 1992 & 0.11 & 0.00 & 0.13 & 0.04 & 0.08 \\
\hline 1993 & 0.12 & 0.00 & 0.13 & 0.05 & 0.09 \\
\hline 1994 & 0.14 & 0.00 & 0.14 & 0.18 & 0.30 \\
\hline 1995 & 0.15 & 0.04 & 0.15 & 0.19 & 0.33 \\
\hline 1996 & 0.17 & 0.04 & 0.17 & 0.31 & 0.40 \\
\hline 1997 & 0.22 & 0.04 & 0.18 & 0.38 & 0.47 \\
\hline 1998 & 0.39 & 0.13 & 0.21 & 0.41 & 0.48 \\
\hline 1999 & 0.40 & 0.30 & 0.31 & 0.43 & 0.58 \\
\hline 2000 & 0.55 & 0.42 & 0.37 & 0.50 & 0.61 \\
\hline 2001 & 0.68 & 0.47 & 0.63 & 0.51 & 0.62 \\
\hline 2002 & 0.72 & 0.63 & 0.67 & 0.51 & 0.63 \\
\hline 2003 & n.a. & 0.70 & 0.69 & 0.51 & 0.66 \\
\hline
\end{tabular}

Source: Copenhagen Economics (2005)

Market opening reflected in Table 1 is expected to have two major effects on network industry prices. One effect is a reduction in prices that would come through reduced pricecost margins (mark-ups) and/or increased efficiency. The second effect is convergence between national prices which, again, would be due to two reasons. On the one hand, EUlevel rules will reduce the price-cost margins and this reduction will be greater in countries where the incumbents had been able to secure higher mark-ups. As a result, we expect price convergence between EU countries. On the other hand, third-party access rights will increase competition and encourage new entry of firms from other member states, which again leads to 
international price convergence. Therefore, market opening reforms in network industries are considered as a highly significant step towards deeper integration not only in terms of creating a level playing field for competition but also in terms of their contribution to the completion of the European single market.

The link between network industry opening and the single market becomes more visible when one considers the impact of market opening on productivity. This impact is expected to be positive because market opening is conducive to higher levels of allocative and/or managerial efficiency. Allocative and managerial efficiency can be expected to increase due to increased competition and the disappearance of subsidies as a bailing-out mechanism that enables inefficient companies to survive. Similarly, the impact of market opening on consumer satisfaction is expected to be positive as customers will enjoy lower prices and increased customer care in a competitive market environment. The impact of market opening reforms on employment, however, is less clear-cut. On the one hand, employment may increase in the relevant industry as new firms enter the market and technological innovation leads to an increase in the product/service range on offer. On the other hand, increased competition may induce companies to substitute capital for labour and lead to a fall in employment at the industry level. Therefore, the net impact on industry-level employment may be uncertain. This uncertainty, however, may be overcome by a positive impact on the rest of the economy that uses the output of the network industries as inputs. To the extent that network industry prices fall, production costs in the rest of the economy will fall and this may lead to an increase in the demand for labour.

Table 2 below provides some evidence on average network industry prices in EU-15. ${ }^{4}$ It suggests that prices in the telecommunications industry has fallen significantly over time and in comparison with the level of inflation. This is in line with the expected effect of market opening. In addition, the fall in local and national call charges can be related to market opening reforms as the telecommunications industry was the first to be liberalised gradually since the beginning of the 1990s. The average price index for electricity reflects a less clearcut trend as it started to increase from 2003 onwards. Nevertheless, the average price index for households and industrial customers has remained below the HICP index - reflecting some price-dampening effect of the market opening reforms in this industry since mid-1990s. The average price index for gas, however, has increased over time and relative to the HICP index despite the fact that the market opening reforms in this industry began at the same time 
as electricity. Reasons put forward for explaining the increase in gas prices include the following: (i) indexation of gas prices to oil prices; (ii) supply bottlenecks caused by network capacity; (iii) significant market power enjoyed by incumbents; and (iv) long durations of sale/purchase contracts. (ERGEG, 2006; EU Commission, 2007).

Table 2: Network industry price indices: EU-15 average prices; $1997=100$

\begin{tabular}{|c|c|c|c|c|c|c|c|c|c|}
\hline & 1997 & 1998 & 1999 & 2000 & 2001 & 2002 & 2003 & 2004 & 2005 \\
\hline \multicolumn{10}{|c|}{ Telecommunications Price Indices 1997=100 (Euro per 10 min call) } \\
\hline Local calls price index: EU-15 & 100.0 & 107.0 & 105.4 & 104.3 & 105.9 & 102.0 & 102.5 & 100.5 & 97.1 \\
\hline National calls price index EU 15 & 100.0 & 82.8 & 69.0 & 53.8 & 40.7 & 36.9 & 35.7 & 31.1 & 29.2 \\
\hline \multicolumn{10}{|c|}{ Electricity prices indices $1997=100$ (Euro per $\mathbf{k W h}$ ) } \\
\hline Electricity household price index & 100.0 & 99.0 & 97.1 & 95.9 & 96.9 & 98.0 & 101.3 & 102.9 & 105.1 \\
\hline Electricity industrial price index & 100.0 & 98.0 & 95.2 & 94.2 & 94.5 & 94.9 & 102.1 & 98.5 & 105.5 \\
\hline \multicolumn{10}{|c|}{ Gas prices indices1997=100 (Euro per Gigajoule) } \\
\hline Gas housholds price index & 100.0 & 101.4 & 95.0 & 102.9 & 127.9 & 121.7 & 123.4 & 121.1 & 133.8 \\
\hline Gas industrial price index & 100.0 & 96.3 & 82.1 & 103.3 & 152.2 & 134.6 & 137.8 & 133.7 & 152.3 \\
\hline HICP, EU 15, 1997=100 & 100.0 & 101.3 & 102.5 & 104.4 & 106.7 & 109.0 & 111.1 & 113.3 & 115.7 \\
\hline
\end{tabular}

HICP = Harmonised index of consumer prices (inflation measure in EU-15).

Source: Eurostat, Structural Indicators at http://epp.eurostat.ec.europa.eu

The mixed picture reflected in Table 2 does not invalidate the expectation that market opening reforms could lead to falling prices in general. However, it calls for caution because market liberalisation, combined with significant market power and low demand elasticities, can also limit the fall in prices and lead to higher levels of price volatility. With respect to limited price falls, Buehler (2005) report that unbundling of an integrated network industry may increase retail prices whereas freer entry may reduce them - with the overall effect remaining uncertain. Even if the net effect is a fall in prices, this may be due to strategies aimed at preventing entry rather than higher levels of competition. In that sense, the fall in price levels can be a reversible outcome - as can be seen from the gas and electricity price levels in Table 2. Borenstein et al (2002) and Bushnell and Mansur (2005) also confirm that market opening reforms can be conducive to increased price volatility. In addition, the demand adjusts to price changes only with a significant time lag. Therefore, price volatility may be conducive to 
divergence from consumer optimality, which requires that marginal costs be equal to marginal benefits.

Another expected effect of market opening is the convergence of national prices as a result of competition. Table 3 below indicates that there has been a degree of convergence between telecommunications prices and industrial consumer prices of electricity. Observable convergence may be related to competition in the telecommunications sector, but it cannot be related to competition in other sectors where prices fell only marginally or increased. In fact, the evidence in Table 3 suggests that prices are more convergent in the electricity and gas sectors where competition is quite limited! This may be due either to the similarity of cost structures or to price coordination in oligopolistic markets. Irrespective of what the cause is, it is clear that the relationship between price convergence and competition is not as straightforward as the proponents of liberalisation would expect.

Table 3: Coefficients of variation (CV) for network industry prices: EU-15*

\begin{tabular}{|c|c|c|c|c|c|c|c|c|c|}
\hline & 1997 & 1998 & 1999 & 2000 & 2001 & 2002 & 2003 & 2004 & 2005 \\
\hline \multicolumn{10}{|l|}{ Telecommunications price } \\
\hline Local call price $\mathrm{CV}$ & 39.3 & 42.5 & 40.5 & 35.5 & 34.2 & 31.0 & 31.3 & 26.1 & 26.3 \\
\hline National call price CV & 48.4 & 52.4 & 48.5 & 47.4 & 42.4 & 38.3 & 37.3 & 41.7 & 36.6 \\
\hline \multicolumn{10}{|l|}{ Electricity price } \\
\hline Electricity household price CV & 28.9 & 29.0 & 27.9 & 26.9 & 28.0 & 23.4 & 22.0 & 21.1 & 22.6 \\
\hline Electricity industrial price CV & 20.2 & 20.1 & 20.9 & 18.9 & 24.3 & 22.7 & 14.7 & 17.0 & 18.3 \\
\hline \multicolumn{10}{|l|}{ Gas prices } \\
\hline Gas household price CV & 16.4 & 13.1 & 14.8 & 15.6 & 23.1 & 21.1 & 18.3 & 15.3 & 17.0 \\
\hline Gas industrial price CV & 14.9 & 16.0 & 18.9 & 12.1 & 21.6 & 14.5 & 12.4 & 12.1 & 14.4 \\
\hline
\end{tabular}

Source: Eurostat, Structural Indicators at: http://epp.eurostat.ec.europa.eu

Similar observations can be made with respect to productivity levels. Market opening reforms are expected to have a positive effect on productivity and this is borne partly by the evidence in Table 4 below. Data availability is limited to two sectors only and the data for electricity and gas is not disaggregated. What is evident form Table 4 is that productivity (either per employee or per hour worked) in some of the network industries has been increasing at faster rates compared to that of total industry. In the telecommunications sector, the productivity 
gains may be related to market opening reforms because liberalisation of this sector began in early 1990s. However, even in this sector, the relationship between market opening and productivity gains should be analysed with care. If we look at Table 1, we can see that market opening in the telecommunications sector remained less than 50\% until 2000. Given this limited market opening, it would be difficult to treat the productivity gains as a consequence of liberalisation. The increase in telecommunications productivity may well be due to technological developments that had begun before liberalisation. Of course, this caveat does not preclude the possibility that the EU has introduced market opening reforms with a view to increase the probability of adaptation to new technologies.

Table 4: Productivity index for network industries and total industry: $1995=100$, volumes.

Labour productivity per employee

Electricity, gas

and water

supply

1990

1991

1992

1993

1994

1995

1996

1997

1998

1999

2000

2001

2002

2003

\section{Communica}

tions

80.5

84.2

87.0

89.2

91.9

100.0

109.7

111.6

118.2

126.4

134.0

138.4

144.6

150.3
75.4

78.8

83.4

88.9

91.5

100.0

106.9

116.9

125.9

140.7

149.7

157.7

170.8

178.4

Total
industry

90.9

92.1

94.4

95.7

98.3

100.0

101.0

102.8

103.9

104.6

106.3

106.9

107.6

108.5

Labour productivity per hour

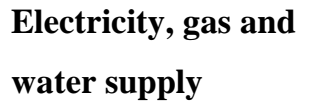

79.4

83.7

86.8

88.6

91.6

100.0

109.9

111.9

118.5

127.9

138.3

143.6

150.9

157.7

$\begin{array}{cc}\begin{array}{c}\text { Communica } \\ \text { tions }\end{array} & \begin{array}{c}\text { Total } \\ \text { industry }\end{array} \\ 74.3 & 89.0 \\ 78.1 & 90.8 \\ 83.1 & 93.4\end{array}$

$88.8 \quad 95.2$

$91.3 \quad 97.8$

$100.0 \quad 100.0$

$106.1 \quad 101.4$

$116.7 \quad 103.7$

$125.6 \quad 104.8$

$141.2 \quad 105.8$

$152.1 \quad 108.5$

$161.6 \quad 109.5$

$176.2 \quad 111.2$

$185.2 \quad 112.5$

Source: Groningen (2005)

The relationship between market opening and productivity gains in the electricity, gas and water supply is even less clear-cut. This is because productivity gains in this sector had been higher than total industry both before and after the introduction of liberalisation reforms in mid-1990s. In both measures, productivity of electricity, gas and water supply had increased 
by approximately 20\% from 1990-95 (before the reforms); whereas the increase in total industry productivity was around $10 \%$. This performance indicates that productivity gains in the electricity, gas and water supply had preceded the introduction of EU-level market opening legislation in mid-1990s.

In addition to the vagueness of the relationship between market opening and productivity, there is the question as to whether productivity gains have been achieved as a result of falling employment. Table 5 below provides some evidence that this may well have been the case in Europe. As can be seen from the table, employment in telecommunications as well as electricity, gas and water supply has fallen gradually over this period. This is in contrast to the gradual increase in total industrial employment. As a result, the percentage share of these sectors in total industrial employment has fallen gradually.

Table 5: Employment in network industries and total industry: EU-15

\begin{tabular}{|l|l|l|l|l|c|}
\hline & $\begin{array}{l}\text { A. Electricity, } \\
\text { gas water supply } \\
\text { employment } \\
\text { (thousands) }\end{array}$ & $\begin{array}{l}\text { B.Telecommunic } \\
\text { ations } \\
\text { employment } \\
\text { (thousands) }\end{array}$ & $\begin{array}{l}\text { C. Total } \\
\text { industry } \\
\text { employment } \\
\text { (thousands) }\end{array}$ & $\begin{array}{c}\text { (A/C)*100 } \\
\text { (\%) }\end{array}$ & $\begin{array}{c}\text { (B/C)*100 } \\
\text { (\%) }\end{array}$ \\
\hline $\mathbf{1 9 9 0}$ & $1,405.0$ & $2,785.3$ & $158,851.6$ & 0.88 & 1.75 \\
\hline $\mathbf{1 9 9 1}$ & $1,396.6$ & $2,788.3$ & $159,647.4$ & 0.87 & 1.75 \\
\hline $\mathbf{1 9 9 2}$ & $1,353.2$ & $2,731.3$ & $157,604.7$ & 0.86 & 1.73 \\
\hline $\mathbf{1 9 9 3}$ & $1,322.2$ & $2,695.1$ & $155,071.0$ & 0.85 & 1.74 \\
\hline $\mathbf{1 9 9 4}$ & $1,290.1$ & $2,639.4$ & $154,801.3$ & 0.83 & 1.71 \\
\hline $\mathbf{1 9 9 5}$ & $1,240.5$ & $2,566.8$ & $156,120.1$ & 0.79 & 1.64 \\
\hline $\mathbf{1 9 9 6}$ & $1,204.7$ & $2,553.8$ & $157,080.1$ & 0.77 & 1.63 \\
\hline $\mathbf{1 9 9 7}$ & $1,170.3$ & $2,516.0$ & $158,622.4$ & 0.74 & 1.59 \\
\hline $\mathbf{1 9 9 8}$ & $1,141.7$ & $2,517.0$ & $161,335.9$ & 0.71 & 1.56 \\
\hline $\mathbf{1 9 9 9}$ & $1,104.3$ & $2,541.4$ & $164,270.7$ & 0.67 & 1.55 \\
\hline $\mathbf{2 0 0 0}$ & $1,063.1$ & $2,636.3$ & $167,653.6$ & 0.63 & 1.57 \\
\hline $\mathbf{2 0 0 1}$ & $1,053.8$ & $2,702.9$ & $169,876.4$ & 0.62 & 1.59 \\
\hline $\mathbf{2 0 0 2}$ & $1,040.7$ & $2,655.9$ & $170,738.1$ & 0.61 & 1.56 \\
\hline $\mathbf{2 0 0 3}$ & $1,021.1$ & Source: Groningen (2005) & 0.60 & 1.53 \\
\hline & & $171,167.1$ & & \\
\hline
\end{tabular}


Combining the evidence in Table 5 and Table 4, it is possible to argue that at least part of the productivity gains in these sectors has been due to falling employment - both in absolute terms and relative to total industrial employment. Despite this, Copenhagen Economics (2005) estimates that market opening reforms have contributed 500,000 jobs over the whole economy. This may well be the case, but when viewed from a political economy perspective, the contrast between that optimistic estimate and the falling employment in the liberalised sectors goes a long way in explaining the hostility of employee organisations to market opening.

The evidence in Tables $1-5$ above suggests that it is possible to relate expected outcomes such as falling prices, increased price convergence, and increased productivity to market opening reforms. However, this relationship is by no means clear-cut. Expected outcomes from market opening tended to be observable both before and after liberalisation reforms. In addition, it is quite difficult to relate expected outcomes to market opening when the incidence of the latter is very low. Market opening indices for all sectors have remained below 0.3 (30\%) until 1995 and below 0.5 (50\%) until 2000. Therefore, at least until mid1990s, it will be quite misleading to establish a causal relationship between market opening and price/productivity/employment performance in the network industries examined above. True, the relationship between market opening and sectoral performance tended to be more meaningful after mid-1990s. However, even then, we are still faced with the perennial second-best problem due to the fact that market opening reforms have removed only part of the existing distortions.

This is why it is not surprising to observe a significant degree of consumer ambivalence towards the liberalisation of network industries in Europe. The majority of network industry consumers tend to express satisfaction with respect to prices, quality and accessibility. However, when one examines the changes in the level of satisfaction against the degree of market opening over time, the findings tend to be mixed in the sense that market opening over time is associated with both increased and decreased customer satisfaction. In addition, the level of satisfaction with respect to access and prices tends to be higher in less liberalised sectors such as gas and electricity compared to more liberalised sectors such as telephony services! Although customer satisfaction is not necessarily a true measure of welfare implications, it reveals significant information about perceptions concerning the welfare effects. 
Table 6: Change in customer responses: EU-15, 2000-2004

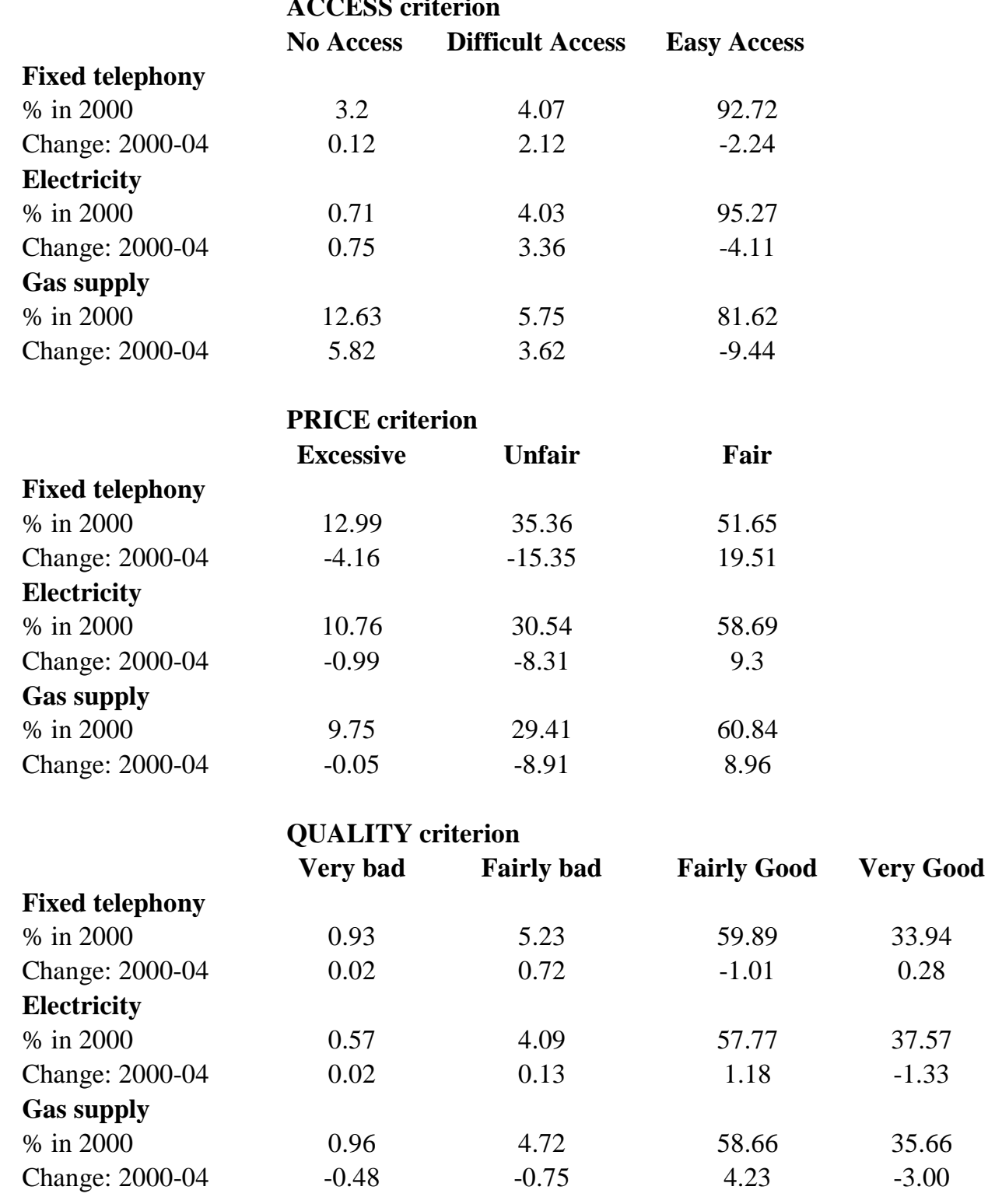

Source: Eurobarometer (Various issues). See also, Fiorio et al (2007)

Table 6 above is based on Eurobarometer survey results in 2000, 2002 and 2004. The table presents the difference in the level of satisfaction between 2000-2002 and 2000-2004 along three performance criteria for network industries: prices, quality, and accessibility. For each industry, the figures in the first row (\% in 2000) represent the distribution of responses in 2000 to the question about a particular criterion such as access, prices and quality. For example, for fixed telephony in 2000, 3.2\% of the respondents indicated that they had no access, $4.07 \%$ indicated difficult access, and $92.72 \%$ indicated easy access to telephone. The 
figures in the second row (Change: 2000-04) represent the difference between the 2004 and 2000 surveys. A negative value indicates a fall and a positive value indicates an increase in the percentage of the respondents. For example, in the fixed telephony case, the percentage of those who reported no access has increased by 0.12 percentage point whereas the percentage of those who reported easy access fell by 2.24 .

As can be seen from Table 6, the level of satisfaction with respect to three performance criteria (i.e., access, prices and quality) as well as the change in satisfaction between 20002004 differ from one industry to the other; and from one criteria to the other. For example, in the most liberalised sector (i.e., fixed telephony), the satisfaction with respect to prices has increased by 19.51 percentage points, but satisfaction with respect to accessibility has deteriorated by 2.24 percentage points. In the least liberalised sector (i.e., gas supply), satisfaction with respect to prices increased by 8.96 percentage points whereas satisfaction with respect to access has fallen by 9.44 percentage points

The survey results reported in Table 6 are aggregate figures for EU-15. Fiorio et al (2007) use response data for each member state and try to establish the determinants of change in customer satisfaction from 2000-2004. Using a maximum likelihood method of estimation, they estimate the impact of various dimensions of the market opening reforms on consumer satisfaction. The estimation is repeated for three performance criteria - i.e., prices, quality, and accessibility. In this estimation, the level of satisfaction is defined as a function of 3 sets of variables: (i) individual characteristics such as sex, education, political views etc.; (ii) country fixed-effects such as GDP per head, Gini index, etc.; and (iii) market opening indicators such as public/private ownership, market share of the incumbent, ease of entry, and degree of vertical integration. The regression results are summarised in Table 7 below. 
Table 7: Summary of the effects of market opening on consumer satisfaction in EU-15:

Fixed telephony, gas and electricity*

\begin{tabular}{|c|c|c|c|c|}
\hline & $\begin{array}{l}\text { Smaller share of } \\
\text { Public ownership }\end{array}$ & $\begin{array}{l}\text { Smaller market share } \\
\text { of incumbent }\end{array}$ & $\begin{array}{l}\text { Larger freedom } \\
\text { to enter }\end{array}$ & $\begin{array}{l}\text { Less vertical } \\
\text { integration }\end{array}$ \\
\hline \multicolumn{5}{|l|}{ Fixed telephony } \\
\hline Access & - & + & + & n.a. \\
\hline Price & - & + & - & n.a. \\
\hline Quality & - & + & - & n.a. \\
\hline \multicolumn{5}{|l|}{ Gas supply } \\
\hline Access & - & - & - & + \\
\hline Price & - & + & n.s. & - \\
\hline Quality & - & + & n.s. & - \\
\hline \multicolumn{5}{|l|}{ Electricity } \\
\hline Access & n.s. & n.s. & + & - \\
\hline Price & + & n.a. & + & - \\
\hline Quality & + & n.a. & + & n.s. \\
\hline
\end{tabular}

+ = Positive effect on consumer satisfaction; - = negative effect on consumer satisfaction; n.a = not available; n.s. = statistically not significant

Source: Fiorio et al (2007: 24)

Results reported in Table 7 confirm the ambivalence that can be captured from table 6. On the one hand, smaller market share of the incumbent tends to have a positive effect on customer satisfaction with fixed telephony and gas supply. This is the case for the three performance criteria concerning prices, accessibility and service quality. However, larger freedom for new entry tends to reduce customer satisfaction in fixed telephony and gas supply, whereas it tends to increase customer satisfaction in electricity supply. Finally, less vertical integration (i.e., separation of producers, network operators and retail suppliers) tends to reduce customer satisfaction with respect to all criteria for which data is available. It is important to note that these results are statistically significant at $1 \%$ or $5 \%$ and are obtained by controlling for individual as well as country characteristics. Given this state of affairs, one has to conclude that either the level of market opening in network industries is not optimal or customer information about market opening is impaired by imperfect information. Whichever conclusion is derived, it ties in with the general conclusion of the second-best theory which states that partial removal of distortions does not necessarily lead to improved welfare. 


\section{Market opening and sectoral performance: cross-country evidence}

The evidence we examine in this section lends further support to the prediction of the secondbest theory. It also enables us to move away from aggregated evidence for EU-15 and examine country-level dynamics. We begin with the impact of market opening reforms on market structure and price transparency. Then, we provide evidence on the extent of correlation between market opening reforms and price levels in the member states for which data is available.

As far as market structure is concerned, the EU Commission (2005) report indicates that significant distortions still exist due to insufficient reduction in the market power of the largest companies in the gas, electricity and telecommunications sectors. With respect to electricity and gas sectors, the Commission reports that 'markets in both sectors remain concentrated, creating scope for incumbent operators to influence prices.' In addition, many wholesale markets are illiquid either due to long term contracts (gas) or because companies are active both in production and in the retail market, limiting the need for wholesale markets.' Finally, the extent of unbundling is quite insufficient. With respect to fixed voice telephony, the Commission reports that the number of operators has increased from 635 to 1237 between 1998 and 2004, but the number of 'major competitors remain low in most countries and the market shares of incumbents are still high.' Finally, in railways, the emergence of competition has been hindered by problems with access to the international network and an inadequate regulatory framework. (EU Commission, 2005: 5, 6).

The assessment in the Commission's report is confirmed by concentration ratios published by ERGEG - the European Regulatory Group for Electricity and Gas. As can be seen from Table 8 below, the three largest companies tend to control between $100 \%$ and $75 \%$ of the market with the exception of Germany and the UK where the concentration ratio ranges between 39\% and 68\%. 
Table 8: The share of 3 largest companies in gas and electricity markets

\begin{tabular}{|l|c|c|c|c|}
\cline { 2 - 5 } \multicolumn{1}{c|}{} & \multicolumn{2}{c|}{ Wholesale markets } & \multicolumn{2}{c|}{ Retail markets } \\
\hline Austria & Gas & Electricity & Gas & Electricity \\
\hline Belgium & 80 & 53 & n.a. & n.a. \\
\hline Denmark & 100 & 95 & 95 & 94 \\
\hline Finland & 95 & 75 & 100 & 40 \\
\hline France & 100 & 61 & 50 & 33 \\
\hline Germany & 98 & 95 & 99 & 97 \\
\hline UK & n.a & 68 & 26 & 40 \\
\hline Greece & n.a & 39 & 75 & 58 \\
\hline Italy & 100 & 98 & 100 & 100 \\
\hline Portugal & 68 & 58 & 44 & 94 \\
\hline Spain & n.a & 72 & n.a & 98 \\
\hline Sweden & 77 & 65 & 76 & 82 \\
\hline The Netherlands & 100 & 88 & 81 & 75 \\
\hline
\end{tabular}

Source: ERGEG (2007: 20, 21).

The European Regulators Group for telecommunications (ERG) also provides evidence that indicates a high level of market concentration. As can be seen from Table 9 below, between $70 \%$ and $100 \%$ of the national regulatory authorities (NRAs) that responded to ERG's survey indicates that there is a significant market power (SMP) enjoyed a by a single company in the four sub-markets of the telecommunications market.

Market power associated with high levels of concentration is a major concern - especially when combined with very low demand elasticities for gas and electricity. The US experience in 1999 and 2000 suggests clearly that companies with high market power are likely to extract high levels of monopoly rents during sudden surges in demand or when supply reaches the maximum capacity level. For example, Borenstein et al (2002) report that, in the summer of 2000 in California, the Power Exchange market prices of electricity increased from $\$ 47.22$ per MWh in May to $\$ 120.20$ per MWh in June, and the price remained over $\$ 100$ for the rest of the year. As a result, expenditures on electricity increased from \$2.04 billion in the summer of 1999 to $\$ 8.98$ billion in the summer of 2000 . Borenstein et al (2002) establish that $59 \%$ of the increase was due to market power of the existing companies, $21 \%$ was due to increase in 
production cost, and 20\% was due to competitive rents. Between 1998 and 2000, oligopoly rents increased by more than ten-folds from $\$ 425$ million to $\$ 4.44$ billion.

Table 9: Single significant market power (SMP) in telecommunications: NRA answers in 2006

\begin{tabular}{|l|c|c|c|c|c|c|c|c|}
\hline & \multicolumn{2}{|l}{ Market 10 } & \multicolumn{2}{l|}{ Market 11 } & \multicolumn{2}{l|}{ Market 12 } & \multicolumn{2}{l|}{ Market 16 } \\
\hline & Yes & No & Yes & No & Yes & No & Yes & No \\
\hline Portugal & & $\mathrm{N}$ & $\mathrm{Y}$ & & $\mathrm{Y}$ & & $\mathrm{Y}$ & \\
\hline Ireland & $\mathrm{Y}$ & & $\mathrm{Y}$ & & n.a. & & $\mathrm{Y}$ & \\
\hline Finland & $\mathrm{Y}$ & & $\mathrm{Y}$ & & $\mathrm{Y}$ & & $\mathrm{Y}$ & \\
\hline Sweden & $\mathrm{Y}$ & & $\mathrm{Y}$ & & $\mathrm{Y}$ & & $\mathrm{Y}$ & \\
\hline Germany & $\mathrm{Y}$ & & $\mathrm{Y}$ & & $\mathrm{Y}$ & & $\mathrm{Y}$ & \\
\hline France & $\mathrm{Y}$ & & $\mathrm{Y}$ & & $\mathrm{Y}$ & & $\mathrm{Y}$ & \\
\hline Italy & $\mathrm{Y}$ & & $\mathrm{Y}$ & & $\mathrm{Y}$ & & $\mathrm{Y}$ & \\
\hline Denmark & $\mathrm{Y}$ & & $\mathrm{Y}$ & & $\mathrm{Y}$ & & $\mathrm{Y}$ & \\
\hline UK & & $\mathrm{N}$ & $\mathrm{Y}$ & & $\mathrm{Y}$ & & $\mathrm{Y}$ & \\
\hline Austria & & $\mathrm{N}$ & $\mathrm{Y}$ & & $\mathrm{Y}$ & & $\mathrm{Y}$ & \\
\hline Spain & n.a. & n.a. & n.a. & n.a. & n.a. & n.a. & n.a. & \\
\hline Greece & n.a. & n.a. & n.a. & n.a. & n.a. & n.a. & Y & \\
\hline Belgium & n.a. & n.a. & n.a. & n.a. & n.a. & n.a. & n.a. & \\
\hline Netherlands & n.a. & n.a. & n.a. & n.a. & Y & & Y & \\
\hline Total Yes/No & $\mathbf{7}$ & $\mathbf{3}$ & $\mathbf{1 0}$ & $\mathbf{0}$ & $\mathbf{1 0}$ & $\mathbf{0}$ & $\mathbf{1 2}$ & $\mathbf{0}$ \\
\hline
\end{tabular}

Source: Derived from NRA answers in ERG (2005b)

Notes:

Market 10: Wholesale transit services in the public telephony network

Market 11: Wholesale unbundled access to metallic loops and sub-loops for the provision of broadband and voice services

Market 12: Bitstream access for transmission of broadband data (M12)

Market 16: Wholesale voice call termination on mobile networks (share of other operators on a given mobile network)

Furthermore, Borenstein et al (2002) also report allocative inefficiencies, which were due to less expensive production by firms with high market power by more expensive production by firms with less market power. The former were able restrict production to increase their monopoly rents by increasing the difference between marginal cost and price. Then, the resulting higher market price has enabled less efficient firms to enter. A typical example of such allocative inefficiencies is the building of higher-cost combined-cycle gas turbine generators to provide base-load power that could be supplied more cheaply by coal-fired plants. 
The US experience took place against an institutional background characterised by high volumes or market trade and price transparency. In Europe, even these conditions are not satisfied. Market trading is low due to long-term contracts and price transparency - especially for small consumers - is not ensured yet. The inadequacy of price transparency is evident from Table 10 below.

Table 10: NRA responses concerning price transparency for gas and electricity

\begin{tabular}{|l|l|l|l|l|l|l|l|c|}
\hline & & & & & & & & Transparency \\
\hline Spain & C1 & C2 & C3 & C4 & C5 & C6 & C7 & Index \\
\hline Sweden & 0.00 & 0.00 & 0.00 & 0.00 & 0.00 & 0.75 & 0.00 & $\mathbf{0 . 1 1}$ \\
\hline France & 0.00 & 0.00 & 0.00 & 0.00 & 0.00 & 1.00 & 1.00 & $\mathbf{0 . 2 9}$ \\
\hline Portugal & 1.00 & 0.25 & 0.25 & 0.25 & 0.25 & 0.25 & 0.00 & $\mathbf{0 . 3 2}$ \\
\hline Ireland & 0.75 & 0.00 & 1.00 & 0.00 & 0.00 & 0.50 & 0.00 & $\mathbf{0 . 3 2}$ \\
\hline Italy & 0.50 & 0.50 & 0.25 & 0.50 & 0.50 & 0.75 & 0.00 & $\mathbf{0 . 4 3}$ \\
\hline Finland & 1.00 & 0.00 & 0.50 & 0.50 & 0.50 & 0.50 & 0.50 & $\mathbf{0 . 5 0}$ \\
\hline Austria & 1.00 & 0.50 & 0.50 & 1.00 & 0.25 & 1.00 & 0.50 & $\mathbf{0 . 6 8}$ \\
\hline Greece & 1.00 & 0.00 & 0.00 & 1.00 & 1.00 & 1.00 & 1.00 & $\mathbf{0 . 7 1}$ \\
\hline Netherlands & 1.00 & 1.00 & 1.00 & 1.00 & 1.00 & 0.00 & 0.00 & $\mathbf{0 . 7 1}$ \\
\hline Belgium & 1.00 & 1.00 & 1.00 & 1.00 & 1.00 & 0.75 & 0.00 & $\mathbf{0 . 8 2}$ \\
\hline Great Britain & 1.00 & 1.00 & 1.00 & 1.00 & 0.50 & 0.75 & 1.00 & $\mathbf{0 . 8 9}$ \\
\hline EU-12 Av. & $\mathbf{0 . 7 7}$ & $\mathbf{0 . 4 4}$ & $\mathbf{0 . 5 4}$ & $\mathbf{0 . 5 6}$ & $\mathbf{0 . 5 0}$ & $\mathbf{0 . 6 7}$ & $\mathbf{0 . 4 2}$ & $\mathbf{0 . 5 6}$ \\
\hline
\end{tabular}

Source: Derived from NRA answers in ERGEG (2005: 14, 15, 18).

Transparency measure:

1.00 = full transparency; $0.25-0.75=$ incomplete transparency; $0=$ no transparency

Transparency criteria:

C1: Publication of list price is required (by default supplier)

C2: Publication of offer price is required (by new supplier or when moving to a different tariff)

C3: Does every supplier publish prices or just the incumbent?

C4: Does supplier provide price information to the regulator or another body?

C5: When are prices published: before or after the price change?

C6: How can a customer compare prices: platform for information and who provides it?

C7: Is comparability of prices ensured?

The index in Table 10 is constructed as follows: For each transparency criterion, we assign a value of 1 if the response from the National Regulatory Authority (NRA) confirms transparency; a value between 0.25 - 0.75 if the answer is qualified; and a value of 0 if the answer confirms that the criterion is not met. The index in the last column and last row is the 
sum of indices in each cell divided by the number of countries (the last row of the table) or by the number of criteria (the last column of the table). The criteria (C1-C7) are described in the note under the table. The table shows that no member state satisfies the condition of full transparency with respect to all criteria. Similarly, no single criterion is satisfied by all member states. In addition, ERGEG (2005) explicitly states that NRAs did not provide detailed information about how transparency is ensured when they report that this is the case. In other words, the index is actually too generous a measure of transparency. Despite this, the overall level of transparency is 0.56 - with significant inter-country variation from 0.11 to 0.89 and inter-criteria variation from 0.42 to 0.77 .

According to ERGEG (2005: 5), the lack of transparency benefits incumbents, undermines the position of new entrants, and aggravates consumer mistrust in the price formation mechanism. That is why the EU Commission (2007: 8) reports that all network users demand more transparency and that there is little harmonisation between member-state transparency requirements. Although price transparency is a necessary condition for efficient functioning of the markets it is by no means sufficient. This is because increased price transparency also increases the risk of collusion between suppliers. Current EU documents recognise this risk, but the regulatory legislation does not address it.

Another question that arises in the context of market opening reforms is whether or not there is a correlation between the level of market opening and the level of prices across countries. To answer this question, we make use of the market opening index (MOI) for each EU member state. The disaggregated data for this index is obtained from Copenhagen Economics directly. We take the value of MOI for a particular sector in a particular EU member state in the last year of observation (2003) and multiply it with the number of years during which the MOI was equal to or greater than 0.3 between 1990 and 2003. The resulting index is labelled as "weighted MOI" in order to account for the significance of the time during which the level of market opening had been significant (i.e., MOI $\geq 0.3$ ). For example, the MOI for the rail passenger transport in Austria in 2003 is 0.4. In addition, Austria has had an MOI index of 0.3 or greater for 7 years. Then the weighted MOI for Austria is 0.4 x $7=2.8$. For Greece, however, the weighted MOI is zero because Greece, until 2003, has not had any year during which the market opening index was equal to or greater than 0.3 . The results are given in Table 11. 
Table 11: Weighted Market Opening Index (MOI) in 2003: EU-15

\begin{tabular}{|l|l|l|l|l|l|}
\hline & $\begin{array}{l}\text { Rail } \\
\text { passenger } \\
\text { transport }\end{array}$ & $\begin{array}{l}\text { Rail } \\
\text { freight } \\
\text { transport }\end{array}$ & Gas & Telecoms & Electricity \\
\hline Austria & 2.80 & 3.68 & 1.38 & 2.72 & 1.98 \\
\hline Belgium & 2.52 & 3.54 & 1.62 & 2.04 & 3.00 \\
\hline Denmark & 2.80 & 4.65 & 1.89 & 6.79 & 4.00 \\
\hline Finland & 3.78 & 3.60 & 0.00 & 3.30 & 6.48 \\
\hline France & 1.92 & 3.08 & 1.96 & 3.70 & 1.65 \\
\hline Germany & 5.70 & 9.40 & 2.20 & 3.30 & 3.30 \\
\hline Greece & 0.00 & 0.00 & 0.00 & 1.06 & 0.82 \\
\hline Ireland & 2.00 & 0.00 & 4.86 & 2.43 & 2.04 \\
\hline Italy & 0.00 & 1.92 & 3.85 & 2.52 & 2.04 \\
\hline Luxemburg & 0.38 & 3.92 & 2.24 & 1.53 & 0.00 \\
\hline The Netherlands & 2.30 & 7.83 & 2.20 & 4.44 & 2.19 \\
\hline Portugal & 2.45 & 0.00 & 0.00 & 2.37 & 1.83 \\
\hline Spain & 0.39 & 0.38 & 3.52 & 3.75 & 2.28 \\
\hline Sweden & 9.38 & 8.85 & 1.96 & 2.28 & 6.32 \\
\hline UK & 10.00 & 11.16 & 6.00 & 10.01 & 12.88 \\
\hline
\end{tabular}

Source: Copenhagen Economics (2005)

Having constructed a weighted MOI that takes into account the length of time during which market opening has been significant, we can now try to establish if there is any correlation between the weighted market opening index and the level of the price index in 2003, which is based on 1997 = 100 for each member state. The Pearson's Rank Correlation coefficients for each pair of variables are given in Table 12 below, which excludes rail transport due to nonavailability of national price data. 
Table 12: Correlation between weighted MOI and price indices for member states: 2003

\begin{tabular}{|l|c|c|}
\hline Variables & $\begin{array}{c}\text { Pearson’s Rank } \\
\text { Correlation Coefficient }\end{array}$ & Significance \\
\hline Weighted MOI in 2003 v. Electricity household price index in 2003 & -0.133 & n.s \\
\hline Weighted MOI in 2003 v. Electricity industrial price index in 2003 & -0.007 & n.s. \\
\hline Weighted MOI in 2003 v. Gas household price index in 2003 & -0.168 & n.s. \\
\hline Weighted MOI in 2003 v. Gas industrial price index in 2003 & 0.336 & $*$ \\
\hline Weighted MOI in 2003 v. Telecom local call price index in 2003 & -0.506 & n.s. \\
\hline Weighted MOI in 2003 v. Telecom national call price index in 2003 & 0.072 & n.s \\
\hline
\end{tabular}

n.s. = not statistically significant; * = significant at $10 \%$

As can be seen from the table, the correlation coefficient is statistically significant only for the local call prices in 2003. The sign of the coefficient is also as expected. As the weighted MOI increases across member states, the price index for local calls tends to fall. This result reinforces the observation we made in relation to price trends at the EU level in Table 2: as market opening deepens, local telephone prices tend to fall across the EU. The correlation coefficients have the correct sign for electricity household and industrial prices and for the gas household prices. However, these coefficients are not statistically significant. Finally, the correlation coefficients have the wrong sign in the case gas industrial prices and national telephone calls. These results suggest that it is not possible to conclude that market opening is necessarily associated with lower prices across member states. This is due to the fact that regulatory quality and institutional baggage in each member state differ too much to allow for a statistically significant correlation between the market opening and prices. This is yet another indication that the second-best problem is relevant to the gradual market opening in European network industries.

\section{Conclusions}

The evidence presented above indicates that market opening reforms in European network industries are more likely to be movements from one second-best to another. Market opening reforms have replaced the natural monopoly under public ownership with oligopolistic markets where ownership could be either public or private. Therefore: (i) it is difficult to establish that market opening reforms have been conducive to a general decline in prices, with the notable exception of telecommunications; (ii) it is equally difficult to conclude that the resulting oligopolistic competition is necessarily more efficient than the previous regime. The 
evidence on the implications of market opening reforms provides a number of indicators as to why this is the case.

With respect to the gas and electricity sectors, the main indicators are: (1) high levels of market concentration and market power; (2) inadequate unbundling of network and supply markets; (3) lack of market integration, especially lack of regulatory oversight for cross border issues; and (4) lack of transparency in price formation. These shortcomings are highlighted not only in the evidence discussed above, but also in EU Commission reports as well as reports by the European Regulatory Group for Electricity and Gas (ERGEG).

There are also country-specific studies, which indicate that market opening in the electricity sector may be conducive to mixed results. For example Thomas (2004: 368) reports that the wholesale market in the UK is dominated by non-transparent long-term contracts; retail competition has disadvantaged small consumers; and integrated generation and retail supply companies dominate the market. With respect to California, Mitra et al (2005: 441-445) report that deregulation (i.e., the Energy Policy Act of 1992 and the Federal Energy Regulatory Commission Orders of 1996) has not led to production or cost efficiency in the electricity market. One is reason is inelastic short-run demand, which prevents the demand side from controlling abusive pricing behaviour. The other is persistent market concentration and oligopolistic behaviour.

In the gas market too, the incumbents remain dominant by largely controlling up-stream gas imports and/or domestic gas production. They trade only a small proportion of their gas on gas exchange markets ('hubs'). Even when trade occurs on gas exchanges, 1-3 players account for $100 \%$ of that trade. Combined with little new entry in retail markets, this situation reduces customer choice and limits competition. (EU Commission, 2007).

In both gas and electricity markets, new entrants do not have effective access to networks despite unbundling provisions. This is because the incumbent operators tend to favour their own affiliates and existing unbundling provisions do not eliminate vertical integration that gives rise to proliferation of incumbent affiliates. Therefore, operational and investment decisions are taken in accordance with the interests of the integrated company and not in the interest of network/infrastructure operations. (EU Commission, 2007: 8; ERGEG, 2006: 6). Finally, there is evident lack of transparency about prices as well as access charges, leading to 
information asymmetries between the incumbents on the one hand and their competitors as well as consumers on the other.

The level of competition is relatively higher in the telecommunications sector. Nevertheless, significant market power enjoyed by a single operator is still prevalent in the majority of the member states. In addition, regulatory provisions for addressing market power are not consistent across member states; and provision of pan-European services is still not allowed. (ERG, 2005). As a result, competition within national markets may have increased but the oligopolistic structure in each EU member-state remains largely intact.

In the rail transport sector, the modality and level of market opening differs significantly between member states. Despite the fact that market opening reforms in this sector have arrived late, they have been followed by an evident trend towards market concentration through mergers and acquisitions. This is likely to increase market power. However, this may be counterbalanced by the emergence of 'European' strategies that enable some operators to operate in several national markets. This, however, will reduce market power if it is associated with new entry, which is not the case. According to Scherp (2005: 4), high market share and strong capital base of the national incumbents make new entry difficult - as it was the case with the 'European Bulls’ alliance set up by five new entrants.

The findings above are closely related to the prediction of the second-best theory - namely that partial removal of existing distortions does not necessarily lead to Pareto-optimality. From a political economy perspective, the deficiencies of the market opening reforms in network industries have a significant implication for the process of European integration. Unlike the single market programme, support for market opening reforms will continue to be uneven between member states and between the various stakeholders. This is due to the fact that these reforms, unlike the removal of non-tariff barriers to trade, do not constitute a move to the first-best. As a move within the second-best environment, market opening reforms cannot guarantee the achievement of Pareto-optimality. In this case, overall welfare may increase, decrease or remain the same. In addition to this uncertainty, even an increase in overall welfare may be associated with worsening of the income/welfare distribution that was associated with the previous level of welfare. In other words, welfare improvement may not be optimal in Paretian sense. This will lead to resistance from stakeholders who are likely to loose and will reduce government willingness to push for the reforms. In addition, 
stakeholders who benefit from market opening reforms at the current level may resist further reform as the latter may cause a fall in their current levels of welfare. As a result, market opening reform in network industry is highly like to be a protracted process, characterised by piecemeal policy making and high incidence of compromises. 


\title{
Endnotes
}

\begin{abstract}
${ }^{1}$ Although we use 'network industries' as a descriptor in this article, this is not the only term used in the literature or public debate. The industries examined here are referred to as utilities, services of general economic interest, or public services. We prefer network industries here because this term does not imply any assumption about the type of ownership. In addition, it also dissociates the services of these industires from pure public goods which are non-rival and non-excludable. Finally, the term 'network industries' is less mouthful when compared to the term 'services of general economic interest' preferred by the European Commission and students of legal studies.

${ }^{2}$ On the role of preference convergence and its linkage to the process of integration, see Ugur (2004).

${ }^{3}$ The Lerner index can be written as follows: $\mathrm{L}=(\mathrm{P}-\mathrm{MC}) / \mathrm{P}=\mathrm{S}_{\mathrm{i}} / \mathrm{E}$, where $\mathrm{L}=$ Lerner index; $\mathrm{P}=$ market price; $\mathrm{MC}=$ marginal cost.; $(\mathrm{P}-\mathrm{MC}) / \mathrm{P}=$ price-cost margin or mark-up, $\mathrm{Si}=$ market share of firm $\mathrm{i}$ in an oligopilistic market with Cournot competiton; and $\mathrm{E}$ = price elasticity of demand;. The Lerner index (the mark-up) is higher the higher is the market share and the lower is the demand elasticity.
\end{abstract}

${ }^{4}$ Data for rail transport is not available. 


\section{References}

Baumol, W. J. (1965). 'Informal judgement, rigorous theory and public policy'. Southern Economic Journal. 32(1), 137-146.

Bhagwati, J. N., V. K. Ramaswami and T. N. Srinivasan (1969). 'Domestic distortions, tariffs and the theory of optimum subsidiy: some further results'. Journal of Political Economy, 77(4), 1005-1019.

Blackorby, C. (1990). 'Economic policy in a second-best environment'. Canadian Journal of Economics, 23(4), 748-771.

Borenstein, S., J. B. Bushnell and F. A. Wolak (2002). 'Measuring market inefficiencies in California's restructured wholesale electricity market'. American Economic Review, 92(5), 1376-1405.

Buehler, S. (2005). 'The promise and pitfalls of restructuring network industries'. German Economic Review, 6(2), 205-228.

Bushnell, J. B. and E. T. Mansur (2005). 'Consumption under nosiy price signals: a study of electricty retail rate deregulation in San Diego'. Journal of Industrial Economics, 53(4), 493513.

Copenhagen Economics (2005). Market Opening in Network Industries: Parts I and II. (Report no. 6201 for DG Internal Market). Retrieved 12 Fenbruary, 2007, from http://www.copenhageneconomics.com/publications.

ERG (2005a) (European Regulators Group for Electronic Communications Networks). 'On the SMP concept for the new regulatory framework’. ERG Working Paper no. (03) 09 rev3. Retrieved on 13 April, 2007, from http://erg.eu.int/documents/index_en.htm.

ERG (2005b) (European Regulators Group for Electronic Communications Networks). Report on experiences with market definition, market analysis and applied remedies, ERG (05) 51. Retrieved on 12 April, 2007, from http://erg.eu.int/documents/index_en.htm.

ERGEG (2005) (European Regulators Group for Electricity and Gas). Report on transparency of energy prices, bills and contracts, E05-CFG-02-07. Retrieved on 20 March, 2007, from http://www.ceer-eu.org/portal/page/portal/ERGEG_HOME/ERGEG.

ERGEG (2006) (European Regulators Group for Electricity and Gas). Assessment of the development of the European energy market, E06-MOR-02-03. Retrieved on 20 March, 2007, from http://www.ceer-eu.org/portal/page/portal/ERGEG_HOME/ERGEG.

EU Commission (2005). Evaluation of the performance of the network industries providing services of general economic interest, SEC(2005) 1781, 20.12.2005: Brussels. 
EU Commission, DG Competition (2007). Report on energy sector inquiry, SEC(2006) 1724, 10.1.2007: Brussels.

Eurobarometer(Special Surveys), Retrieved on various dates from 10-23 January, 2007, from European Commission site at http://ec.europa.eu/public_opinion/archives/eb_special_en.htm.

Fiorio, C. V., M. Florio, S. Salini and P. Ferrari (2007). 'Consumers' attitudes on services of general interest in the EU: accessibility, price and quality 2000-2004'. Social Science Research Network Electronic Paper Collection. Retrieved on 21 January, 2007, from $\underline{\text { http://ssrn.com/abstract=958939 . }}$.

Geradin, D. (2006). 'The liberalization of network industries in the European Union: where do we come from and where do we go'. Annual Report of the European Regulation for Electricity and Gas, Prime Minister's Office, Economic Council of Finland: Helsinki.

Groningen Growth and Development Centre (2005). 60-Industry Database. Data retrieved on 17 December, 2006, from http://www.ggdc.net/.

Jarrell, G.A. (1978). 'The demand for state regulation of the electric utility industry'. Journal of Law and Economics, 21(2), 269-95.

Lipsey, R. G. (2007). 'Reflections on the general theory of second best at its golden jubilee'. Retrieved on 18 April, 2007, from http://www.sfu.ca/ rlipsey.

Lipsey, R. G. and K. Lancaster (1956). 'The general theory of second best'. The Review of Economic Studies, 24(1), 11-32.

Mitra, A., D. Stoler and Lin, T-C (2005). 'Deregulation of the electric utility industry: an empirical study’. Public Finance and Management, 5(3), 439-453.

Martin, R., M. Roma, and I. Vansteenkiste (2005). 'Regulatory reforms in selected EU network industries’. European Central Bank Occasional Paper Series, no. 28.

Napolitano, G. (2005). 'Towards a European legal order for services of general economic interest’. European Public Law, 11(4), 565-581.

Rakowski, J. (1980). 'The theory of second best and the competitive equilibrium model'. Journal of Economic Issues, 14(1), 197-207.

Scherp J. (2005). 'Railway (de-)regulation in EU member states and the future of European rail'. CESifo Dice Report 4/2005. Retrieved on 16 April, 2007, from http://ec.europa.eu/transport/rail/overview/articles_en.htm.

Thomas, S. (2004). 'Evaluating the British model of electricity deregulation'. Annals of Public and Cooperative Economics, 75(3), 367-398. 
Ugur, M. (2004). '(Re)theorising globalisation and European integration: a political economy approach’. European Political Economy Review, 2(1), 74-103.

Upadhyaya, K.P. and F. G. Mixon Jr. (1995). 'Regulatory capture and the price of electricity: evidence from time series estimates'. International Journal of Social Economics, 22(1), 16-23.

Upadhyaya, K.P. and J. E. Raymond (1994). 'What can regulators regulate? The case of electricity revisited’. Department of Economics, Auburn University, Auburn, AL. 